\title{
ANTESEDEN DAN KONSEKUENSI MORAL PAJAK (Studi Pada Wajib Pajak Orang Pribadi di Kota Pekanbaru)
}

\author{
Yesi Mutia Basri dan Al Azhar \\ Program Studi Akuntansi, Fakultas Ekonomi dan Bisnis, Universitas Riau Pekanbaru \\ E-mail: i.yesimutia@yahoo.com
}

\begin{abstract}
This study aims to examine socio-demographic factors (age, gender, and education), personal financial experience and political attitudes as a moral determinant of individual tax payers. This study also examines the consequences of tax morale that is tax evasion. This study uses 100 samples of individual tax payers registered in KPP Pratama Tampan Pekanbaru. By using regression analysis, the results showed that socio demographic factors, i.e. age, gender and education, did not affect the tax morale and employment status, furthermore as an entrepreneur also has no effect on tax morale. However, trust and satisfaction on democracy and politics affect tax morale. In addition, tax moral also affect the behavior of tax evasion.
\end{abstract}

Keywords: age, gender, education, income, entrepreneurship, satisfaction, trust, tax morale, tax fraud

\section{PENDAHULUAN}

Pajak merupakan salah satu sumber utama penerimaan pemerintah yang digunakan untuk memenuhi kebutuhan belanja negara dalam rangka pembangunan nasional. Walaupun pajak merupakan sumber utama dalam pembangunan namun penerimaan pajak di Indonesia masih rendah yang ditunjukkan dengan tax ratio Indonesia baru sekitar $11 \%$ terhadap Produk Domestik Bruto (PDB). Angka ini masih sangat rendah jika dibandingkan dengan negara-negara di kawasan Asia Tenggara. Angka tersebut bahkan jauh lebih rendah jika dibandingkan dengan Singapura 14\%, Filipina 12,9\%, Thailand 16,5\%, dan Malaysia 16,1\% (Infobank News, 2015).

Pada tahun 2015 realisasi penerimaan pajak sebesar Rp1.060 triliun dari targetnya yaitu Rp1.294,25 triliun atau sebesar $85 \%$. Dari jumlah tersebut hanya Rp9 triliun merupakan pajak dari orang pribadi di luar karyawan. Meskipun melampaui targetnya pada tahun 2015, penerimaan pajak dari Wajib Pajak Orang Pribadi secara nominal masih terlalu rendah (Kemenkeu.go.id).
Pemerintah melalui Direktorat Jenderal Pajak (DJP) yang berada di bawah Departemen Keuangan terus melakukan upaya-upaya agar pengelolaan penerimaan pajak semakin baik. Upaya tersebut dapat dilakukan dengan kebijakan perpajakan maupun administrasi perpajakan. Melalui kebijakan perpajakan DJP berupaya memperbaharui kebijakan-kebijakan perpajakan yang tertuang dalam peraturan perundang-undangan perpajakan. Sedangkan melalui administrasi perpajakan DJP berupaya memperbaharui sistem internal DJP agar dapat memberikan pelayanan terbaik bagi Wajib Pajak.

Adanya berbagai masalah perpajakan pada saat ini, terutama yang disebabkan oleh perilaku korupsi aparat pajak, dikhawatirkan akan menyebabkan keengganan masyarakat untuk membayar pajak. Belum optimalnya penerimaan PPh orang pribadi juga memerlukan sebuah studi dan pengembangan model moral dan kepatuhan pajak untuk mengatasi masalah tersebut. Fenomena adanya berbagai kasus pajak yang bisa menyebabkan masyarakat enggan membayar pajak, masih rendahnya 
penerimaan pajak dari wajib pajak orang pribadi, dan keterbatasan pendekatan yang dilakukan studi-studi sebelumnya dalam mengembangkan moral dan kepatuhan pajak, merupakan isu-isu strategis yang menjadi latar belakang penelitian ini.

Upaya penegakan dibuat di manamana untuk mendorong kepatuhan pajak. Namun, penelitian empiris telah berulang kali menunjukkan bahwa kepatuhan tidak sepenuhnya dijelaskan oleh imbalan dan hukuman yang dikenakan melalui tarif pajak, denda dan penalti lain atau probabilitas audit (Lago-Peñas, S. Lago-Peñas, 2010).

Penelitian menunjukkan bahwa penegakan hukum yang tinggi akan mengurangi terjadinya kejahatan pajak. Allingham \& Sandmo (1972) dan Srinivasan (1973) yang menyatakan bahwa pemeriksaan pajak, sanksi dan denda yang berat merupakan strategi yang paling ampuh untuk memerangi kejahatan pajak. Hasil penelitian oleh Schneider \& Enste $(2000,2002)$ menunjukkan bahwa penegakan hukum yang lemah, kesewenang-wenangan penegakan hukum dan lemahnya peraturan perpajakan mendorong terjadinya korupsi dan penggelapan pajak. Namun penelitian Taher (2011) dan Fuadi (2012) menunjukkan bahwa penegakan hukum yang berlaku justru tidak berpengaruh pada perilaku wajib pajak dalam membayar pajak.

Sebuah penjelasan alternatif diterima secara luas untuk inkonsistensi antara penegakan dan kepatuhan pajak didasarkan pada Konsep "tugas warga negara" (Orviska dan Hudson, 2003) atau "semangat pajak", sintetik didefinisikan sebagai kewajiban moral atau intrinsik motivasi untuk membayar pajak (Torgler dan Schneider, 2007). Diabaikan selama beberapa dekade (lihat Andreoni et al., 1998), moral pajak telah berubah menjadi isu utama dalam penelitian empiris paling baru pada kepatuhan pajak dan buku-buku terbaru oleh Torgler (2007) dan Kirchler (2007).
Lago-Peñas, S. Lago-Peñas (2010) melakukan penelitian mengenai determinan moral pajak pada negara-negara di Eropa dengan menggunakan karakteristik sosial demografi, pengalaman keuangan personal dan sikap politik. Hasil penelitiannya menunjukkan semangat pajak dibentuk oleh karakteristik sosio-demografis, pengalaman keuangan personal dan sikap politik. Semangat pajak secara positif berhubungan dengan usia, agama, pendapatan, kepuasan dengan demokrasi, kepercayaan politisi, dan perjanjian dengan redistribusi. Sebaliknya, semangat pajak berkorelasi negatif dengan wirausaha dan pendidikan. Kemudian, terdapat hubungan yang signifikan negatif antara etnis fraksionalisasi dan kepatuhan pajak. Redistribusi daerah dalam negara relevan untuk menjelaskan semangat pajak, khususnya di negara-negara federal. Orang yang tinggal di daerah-daerah yang kaya kurang rentan terhadap kepatuhan pajak. Pajak atas penghasilan dan keuntungan lebih berkorelasi negatif dengan semangat pajak dibandingkan dengan pembayaran jaminan sosial atau pajak konsumsi.

Torgler dan Schneider (2007) telah melakukan penelitian di Spanyol, Switzerland dan Belgium. Penelitiannya menemukan bahwa budaya dan perbedaan daerah berpengaruh terhadap moral pajak (tax morale). Kepercayaan dalam sistem hukum pemerintah dan parlemen, kebanggan nasional, dan sikap mendukung demokrasi memiliki dampak yang positif terhadap moral pajak.

Kaplan, Newberry, dan Reckers (1997) menggunakan konsep moral sebagai variabel perilaku untuk menjelaskan terjadinya penggelapan pajak. Trivedi, Shehata, dan Lynn (2003) membangun model untuk menganalisis perilaku kepatuhan wajib pajak dengan lebih komprehensif, yaitu dengan pendekatan ekonomi dan perilaku wajib pajak. Mengacu pada penelitian Trivedi et al. (2003), penelitian ini menganalisis tingkat 
moral dan kepatuhan pajak dengan kedua pendekatan tersebut dan sekaligus menformulasikan model untuk meningkatkan tingkat moral dan kepatuhan pajak orang pribadi.

Seperti yang dikemukakan Torgler (2012) moral pajak yang dimiliki seseorang menentukan terjadinya perilaku kepatuhan pajak. Torgler dan Murphy (2005) menyatakan moral pajak sebagai prinsipprinsip moral atau nilai-nilai yang dimiliki oleh individu tentang membayar pajak mereka. Penelitian ini mengembangkan penelitan Lago-Peñas, S. Lago-Peñas (2010) yang menguji faktor sosio demografi, pengalaman keuangan pribadi dan sikap politik sebagai penentu moral wajib pajak orang pribadi di negara-negara Eropa. Penelitian ini juga menguji konsekuensi dari moral pajak yaitu kecurangan pajak. Cahyonowati (2011) telah meneliti hubungan moral pajak dengan kepatuhan pajak pada wajib pajak orang pribadi di KPP Semarang. Hasil penelitiannya menunjukkan bahwa moral pajak berpengaruh terhadap kepatuhan pajak. Hal ini juga didukung oleh oleh penelitian Torgler dan Schneider (2004) yang menemukan bahwa tax morale seorang wajib pajak sangat mempengaruhi perilaku wajib pajak lainnya. Sebagaimana yang dikemukakan Kaplan, Newberry, dan Reckers (1997) bahwa moral pajak mempengaruhi perilaku untuk melakukan kecurangan pajak. Berdasarkan uraian di atas maka dapat disimpulkan rumusan masalah sebagai berikut apakah demografi (umur, jenis kelamin, pendidikan) berpengaruh terhadap moral pajak, apakah pengalaman keuangan pribadi (tingkat ekonomi, wirausaha) berpengaruh terhadap moral pajak, apakah sikap politik (kepuasan pada demokrasi, kepercayaan pada politisi) berpengaruh terhadap moral pajak, apakah moral pajak berpengaruh terhadap kecurangan pajak.

\section{KAJIAN LITERATUR DAN PENGEMBANGAN HIPOTESIS}

\section{Kajian literatur}

Moral Pajak dan Kecurangan Pajak

Banyak faktor yang mempengaruhi penerimaan pajak antara lain faktor ekonomi makro, efektifitas sistem perpajakan yang dilaksanakan, perdagangan, iklim dunia bisnis dan usaha dll, namun sebagaimana dinyatakan oleh Trivedi dan Lynn (2003), kepastian adanya kepatuhan pajak (tax compliance) yang tinggi adalah tujuan utama yang sangat penting bagi pemerintah dalam upaya pendanaan untuk membiayai pengeluaran publik dan pembangunan untuk mencapai kesejahteraan masyarakat. Oleh karena itu kepatuhan pajak adalah faktor yang terpenting dari seluruh faktor yang mempengaruhi penerimaan pajak. Kasadaran masyarakat yang tinggi akan mendorong semakin banyak masyarakat memenuhi kewajibannya untuk mendaftarkan diri sebagai wajib pajak, melaporkan dan membayar pajaknya dengan benar sebagai wujud tanggung jawab berbangsa dan bernegara. Semakin besar tingkat kepatuhan masyarakat membayar pajak maka penerimaan pajak akan semakin meningkat (James dan Nobes, 1997:137). Kepatuhan pajak tersebut mencerminkan tingkat kerelaan masyarakat dalam memenuhi kewajiban perpajakannya sesuai dengan peraturan yang berlaku. Adalah Allingham dan Sandmo (1972) yang mengembangkan pertama kali teori kepatuhan pajak.

Teori ini berpendapat bahwa kesediaan WP untuk melaporkan pendapatan dalam SPT-nya (declared income) bergantung pada income, tarif, kemungkinan pemeriksaan (audit) dan sanksi. Pelaporan pendapatan akan meningkat seiring dengan meningkatnya probabilitas audit dari deteksi fiskus atau sanksi (penalty rate) yang akan dikenakan. Sedangkan dampak dari besarnya tarif dan pendapatan bergantung perilaku individu terhadap resiko. Pemahaman ini mengasumsikan sedemikian tingginya tingkat ketidakpatuhan dari sisi ekonomi. Perilaku wajib pajak didasarkan pada keinginan 
memaksimalkan utility yang diharapkan. Teori ini berkeyakinan tidak ada individu bersedia membayar pajak secara sukarela (voluntary compliance). Secara mendasar diyakini bahwa penghindaran pajak tergantung dan berbanding terbalik pada kemungkinan dilakukan pemeriksaan (audit) dan potensi terkena sanksi dan ukuran sanksi yang dikenakan. Bagian penghasilan yang diselundupkan menurun sejalan dengan semakin tingginya denda dan sanksi. Sementara pengaruh besarnya pendapatan dan tarif pajak masih samar-samar. Oleh karena itu individu akan selalu menentang untuk membayar pajak dengan benar (risk aversion), dan karenanya harus dilakukan pemeriksaan. Pemahaman pandangan ini mendasari kebijakan pemeriksaan di Indonesia. Dengan demikian teori ini sematamata meletakkan kepatuhan pajak pada pundak tanggung jawab wajib pajak, sementara perilaku aparat pajak (fiskus) diabaikan sama sekali. Dalam prakteknya perilaku kepatuhan wajib pajak juga berbanding lurus dengan bagaimana fiskus memberlakukan mereka.

Frey dan Feld (2002) menjelaskan bahwa wajib pajak akan merespon positif atas bagaimana otoritas pajak memperlakukan mereka. Khususnya kesediaan moral wajib pajak untuk membayar pajak atau tax morale akan meningkat ketika pejabat pajak menghargai dan menghormati mereka (respect), dan kemudian berdampak terhadap masyarakat yang merasa puas dan meyakini bahwa pajak yang dipungut benar-benar dipergunakan untuk kebutuhan publik. Sebaliknya jika pejabat pajak menganggap wajib pajak semata-mata sebagai subyek yang harus dipaksa untuk membayar pajaknya, maka wajib pajak cenderung merespon dengan aktif untuk mencoba menghindar membayar pajak. Beberapa faktor yang mempengaruhi tax morale, (Frey 1997) seperti; persepsi adanya kejujuran aparat; kepercayaan terhadap instansi pemerintah; penghargaan atau rasa homat dari aparat pajak (respect); dan sejumlah sifat-sifat individu lainnya. Dengan demikian mengharapkan tingkat kepatuhan pajak yang tinggi, selalu disertai adanya keseimbangan antara tingkat kepatuhan wajib pajak pada satu sisi dan kepatuhan fiskus dalam melaksanakan aturan perpajakan pada sisi lainnya. Penelitian penulis pada tahun 2008 di Jawa Timur menunjukkan bahwa naik turunnya tingkat kepatuhan pajak wajib pajak tidak berbanding lurus dengan peningkatan penerimaan pajak. Faktor perilaku aparat pajak justru sebaliknya. Kepatuhan fiskus yang tinggi menyiratkan tindakan fiskus yang menghargai wajib pajak (respect) dan yang tidak sewenang-wenang memperlakukan wajib pajak secara otoriter. Pajak yang dibayarkan dianggap sebagai sebuah pengeluaran yang musti dilakukan karena kepemilikan/manfaat dari obyek pajak yang ada. Sebaliknya tingkat kepatuhan pajak yang rendah, mencerminkan adanya ketidakrelaan masyarakat dan fiskus dalam melaksanakan kewajiban dan aturan perpajakan sesuai dengan peraturan perundang-undangan yang berlaku.

Meningkatnya permohonan keberatan pajak dari tahun ketahun adalah merupakan sikap protes Wajib Pajak (WP) terhadap hasil pemeriksaan fiskus yang masih menganggap WP sebagai satu-satunya objek kepatuhan pajak. Dampak dari dispute ini adalah membengkaknya tunggakan pajak. Walau secara legal (Pasal 34 UU KUP Tahun 2008) DJP dapat melakukan pemeriksaan pajak dalam upaya meningkatkan kepatuhan, namun sudah waktunya paradigma WP selalu salah perlu ditinjau ulang sebagaimana teori tax moral menjelaskan bahwa WP akan merespon positif dan sedia membayar pajak dengan baik jika ada respect baik dari pihak fiskus.

\section{PENGEMBANGAN HIPOTESIS} Jenis kelamin 
Meskipun belum banyak dukungan riset, terdapat kecenderungan bahwa perempuan lebih jujur dan patuh dibandingkan laki-laki. Penelitian terdahulu mengenai kepatuhan pajak juga menemukan bahwa laki-laki kurang patuh terhadap peraturan perpajakan dibandingkan dengan perempuan (Tittle, 1980). Demikian pula, perempuan cenderung lebih mementingkan masalah etika dibandingkan laki-laki; misalnya, penelitian Frank (1996) telah menunjukkan, wanita lebih memperhatikan pertimbangan etis ketika memilih majikan. Hasil terbaru oleh Torgler dan Valev (2010) mengungkapkan kesediaan lebih tinggi untuk kepatuhan pajak di kalangan wanita sehingga memungkinkan rendahnya kecurangan pajak. Berdasarkan temuan tersebut, penelitian ini memprediksi bahwa:

H1a: Terdapat hubungan positif antara jenis kelamin yaitu tingkat moral pajak WP wanita akan lebih tinggi daripada pria.

Umur

$$
\begin{aligned}
& \text { Modal sosial (social capital) individu } \\
& \text { semakin bertambah seiring dengan } \\
& \text { bertambahnya usia. Individu-individu dewasa } \\
& \text { akan semakin terikat dalam suatu komunitas. } \\
& \text { Perilaku individu dewasa juga semakin terikat } \\
& \text { dengan perilaku dalam komunitas. Efek } \\
& \text { positif dari pembatasan ini adalah perilaku } \\
& \text { individu untuk menghindari kos yang timbul } \\
& \text { dari sanksi sosial termasuk juga sanksi sosial } \\
& \text { karena melakukan penggelapan pajak. } \\
& \text { Torgler dan Valev (2004) juga menemukan } \\
& \text { bahwa umur berkorelasi negatif dengan } \\
& \text { pelanggaran aturan. Berdasarkan argumen } \\
& \text { terse but, penelitian memprediksi bahwa: }
\end{aligned}
$$

\section{$\mathrm{H} 1 \mathrm{~b}$ : Terdapat hubungan positif antara umur} wajib pajak dengan moral pajak.

\section{Pendidikan}

Semakin tinggi tingkat pendidikan individu maka tingkat pengetahuan mengenai peraturan perpajakan akan semakin luas dan lebih memahami manfaat membayar pajak dibandingkan individu yang berpendidikan lebih rendah. Pada sisi lain, individu yang berpendidikan memiliki pemikiran yang lebih kritis mengenai hukum pajak dan pembelanjaan negara dari penerimaan pajak. Selain itu, individu tersebut juga lebih mahir untuk mensiasati aturan pajak baik secara legal maupun ilegal yang berakibat pada penurunan level kepatuhan

pajak.

Torgler dan Schneider (2007)
berpendapat bahwa individu lebih berpendidikan lebih mungkin untuk tahu lebih banyak tentang hukum pajak dan koneksi fiskal dan dengan demikian lebih baik menyadari manfaat dan layanan negara menyediakan dari pembayar pajak tidak berpendidikan. Namun, mereka juga mungkin lebih penting dari bagaimana negara bertindak dan menghabiskan pendapatan pajak. Dengan demikian, prediksi yang jelas sulit untuk membuat. Menurut bukti empiris mereka, pendidikan berkorelasi negatif dengan semangat pajak di tiga negara mereka menganalisis, Swiss, Belgia dan Spanyol, tetapi tidak statistik signifikan di sebagian besar spesifikasi.

H1c: Tingkat pendidikan berpengaruh terhadap moral pajak.

\section{Pengalaman Keuangan Pribadi (Personal Financial Experiences) Tingkat Ekonomi}

Duch et al. (2000) telah menunjukkan untuk evaluasi ekonomi nasional, warga diri tertarik memiliki pendapat yang mencerminkan keadaan ekonomi khusus mereka (misalnya, status pekerjaan, pendapatan). Dengan demikian, individu yang mendapatkan manfaat yang lebih besar dari negara harus cenderung memiliki pemahaman yang lebih baik dari perlunya membayar pajak dibandingkan orang-orang yang tidak. Torgler dan Schneider (2004) juga menyatakan sulit untuk menilai secara teoritis hubungan antara tingkat ekonomi 
dengan tingkat kepatuhan Pajak. Keputusan individu untuk patuh pajak dengan tingkat penghasilan tertentu didasarkan pada preferensi risiko dan tarif progresif yang berlaku. Tarif pajak progresif mendorong individu berpenghasilan besar untuk meraih tax return dengan melakukan penggelapan pajak. Sedangkan individu berpenghasilan rendah kurang berani untuk mengambil risiko penggelapan pajak karena hal ini akan berakibat penurunan kekayaan jika pelanggaran pajak terdeteksi fiskus.

Selain itu, sejalan dengan penelitian sebelumnya Lago-Peñas, S. Lago-Peñas (2010) status yang wiraswasta adalah dimasukkan sebagai regressor (a). Wiraswasta biasanya menikmati lebih banyak kesempatan untuk menipu pada pajak mereka. Pendapat tentang pajak moral pajak mungkin mencerminkan ex-post pembenaran Berdasarkan uraian tersebut, maka dirumuskan hipotesis sebagai berikut:

\section{H2a: Pendapatan berpengaruh terhadap moral pajak.}

$\mathrm{H} 2 \mathrm{~b}$ : Status wirausaha berpengaruh terhadap moral pajak.

\section{Sikap Politik (Political Attitudes) Kepuasan Pada Demokrasi}

Torgler (2002) berpendapat bahwa tax morale kemungkinan dipengaruhi oleh latar belakang sebuah institusi. Institusi yang menghargai keinginan warga negara akan memperoleh dukungan yang lebih banyak dari rakyatnya. Sebuah pemerintahan yang telah berkomitmen untuk menerapkan demokrasi langsung bisa diartikan bahwa pemerintah membatasi kekuatan yang dimilikinya dan hal ini memberikan sinyal bahwa wajib pajak merupakan orang yang bertanggung jawab. Demokrasi langsung juga menunjukkan bahwa warga negara bukan orang bodoh sehingga preferensi wajib pajak harus dipertimbangkan dalam proses politik. Semakin tinggi partisipasi wajib pajak dalam proses pengambilan keputusan politis, maka kepercayaan terhadap kontrak politik dan juga tax morale akan semakin tinggi. Wajib pajak memiliki hak untuk mengontrol dan memonitor kontrak pajak dengan pcmerintah melalui referendum dan renegosiasi kontrak pajak sehingga kemudahan wajib pajak untuk menyampaikan aspirasinya mengenai isu-isu perpajakan (misalnya aspirasi mengenai alokasi penggunaan pajak) akan meningkatkan tax morale.

Torgler (2002) menemukan bahwa partisipasi politik berpengaruh positif terhadap kepatuhan pajak sehingga memungkinkan rendahnya penggelapan pajak. Hasil penelitian Lago-Peñas, S. LagoPeñas (2010) juga menunjukkan bahwa partisipasi berpolitik mempengaruhi moral pajak Berdasarkan uraian terse but di atas maka dapat disusun hipotesis bahwa:

H3a: Kepuasan pada sistem demokraksi mempengaruhi moral pajak wajib pajak.

\section{Kepercayaan Pada Politisi}

Pendapatan pemerintah dan karenanya perlindungan bagian dari pendapatan mereka sendiri dan kekayaan dari pajak mungkin lebih mungkin untuk menipu pajak mereka. Tapi selain dari bias ideologis, ada sikap politik lain yang mempengaruhi semangat pajak, khususnya politik ketidakpuasan atau perasaan subjektif dari ketidakberdayaan, sinisme, dan kurangnya kepercayaan dalam proses politik, politisi, dan lembaga-lembaga demokrasi, tanpa ditemani oleh pertanyaan dari rezim politik (Montero dan Torcal 2006, 6).

$$
\text { Ketidakpuasan menyebabkan }
$$

berkurangnya minat dalam politik dan cenderung yang lebih rendah untuk membayar pajak. Sebagai Feld dan Frey (2007) berpendapat, proses politik dirasakan adil dan sah dorongan moral pajak. Kontrak antara pembayar pajak dan otoritas akan melibatkan tidak hanya penyediaan barang publik dan pembayaran pajak, tetapi juga kontrak psikologis tentang cara kedua bagian 
memperlakukan satu sama lain dan kewajaran prosedur yang mengarah ke hasil politik. Selain itu, Schnellenbach (2006) menunjukkan bahwa penggelapan pajak bisa dipandang sebagai mekanisme untuk menghukum pemerintah yang ingin meningkatkan penerimaan pajak dan bukan mematuhi kebijakan yang disukai dari wajib pajak.

H3b: Kepercayaan pada politisi berpengaruh pada moral pajak.

\section{Pengaruh Moral Pajak Terhadap Kecurangan Pajak}

Menurut Kamus Besar Bahasa Indonesia (2007), moral merupakan ajaran tentang baik buruk yang diterima umum mengenai perbuatan, sikap, kewajiban, dan sebagainya. Menurut Velasquez (2005), moralitas diartikan sebagai pedoman yang dimiliki individu atau kelompok mengenai apa itu benar dan salah atau baik dan jahat.

Moral perpajakan (tax morale) dapat didefinisikan sebagai motivasi intrinsik untuk mematuhi dan membayar pajak sehingga berkontribusi secara sukarela pada penyediaan barang-barang publik (Torgler \& Schneider, 2004). Moral perpajakan merupakan determinan kunci yang dapat menjelaskan mengapa orang jujur dalam masalah perpajakan. Torgler dan Schneider(2004) menemukan bahwa tax morale seorang wajib pajak sangat dipengaruhi oleh perilaku wajib pajak lainnya.

Penelitian yang dilakukan sebelumnya oleh Parker et al (1995), dan Mustikasari (2007), menunjukkan bahwa tingkat moral individu secara signifikan berpengaruh terhadap kepatuhan pajak. Demikian pula penelitian yang dilakukan oleh Wenzel (2004), menyatakan bahwa individu yang memiliki norma individu yang kuat dalam kejujuran dan moral pajak lebih berperilaku patuh. Hipotesis yang dapat dikemukakan sebagai berikut:

H4: Moral pajak berpengaruh negatif terhadap kecurangan pajak.

\section{METODOLOGI PENELITIAN}

\section{Populasi dan Teknik Penarikan Sampel}

Populasi dalam penelitian ini adalah Wajib Pajak yang terdaftar pada KPP Pratama Pekanbaru. Teknik sampling yang digunakan adalah convenience sampling yaitu pengambilan sampel dengan cara yang paling mudah menurut peneliti.

\section{Teknik Pengumpulan Data}

Pengumpulan data dilakukan dengan cara mengantarkan kuisioner secara langsung kepada responden dalam penelitian ini. Pada waktu yang ditentukan kuisioner akan dijemput kembali.

\section{Operasionalisasi Variabel Kecurangan Pajak}

Kecurangan pajak menggunakan instrumen yang dikembangkan oleh McGee (2006). Secara umum terdapat 3 pandangan dasar mengenai etika kecurangan pajak. Pertama pandangan bahwa kecurangan pajak tidak etis, kedua, kecurangan pajak kadangkadang etis dan ketiga, kecurangan pajak etis. Variabel diukur dengan menggunakan 10 item pertanyaan yang diukur dengkan skala likert dengan poin $1 \mathrm{~s} / \mathrm{d} 5$ yaitu sangat tidak setuju s/d sangat setuju. Skor rendah menunjukkan penerimaan tax evasion dan skor yang tinggi menunjukkan ketidaksetujuan terhadap tax evasion.

\section{Moral pajak}

Moral pajak umumnya didefinisikan dalam literatur pajak sebagai motivasi intrinsik untuk membayar pajak. Hal ini dijelaskan oleh Torgler dan Murphy (2005) sebagai prinsip-prinsip moral atau nilai-nilai dimiliki oleh individu tentang membayar pajak mereka. Untuk menjelaskan moral 
pajak sebagai salah satu faktor yang mempengaruhi kepatuhan pajak, sangat penting untuk memahami unsur-unsur yang membentuk moral pajak Moral pajak diukur dengan menggunakan lima item pertanyaan yang diadopsi dari Tax moral-Fillipine (2013).

\section{Demografi}

\section{Umur}

Umur didefinisikan adalah umur responden yang diukur dengan skala numerik tingkat pendidikan. Yaitu tingkat pendidikan yang telah dicapai yang diukur dengan skala kategori yaitu $1=<$ SLTA, $2=$ Sarjana, $3=>$ S2 . Jenis kelamin. Jenis kelamin responden untuk laki-laki diberi kode 1 dan perempuan diberi kode 0 .

\section{Pengalaman Ekonomi \\ Pendapatan}

Pendapatan adalah variabel kategoris menggambarkan bagaimana orang merasa pendapatan rumah tangga mereka saat ini: "hidup nyaman dengan Pendapatan ini", "mengatasi penghasilan hadir", "menemukan kesulitan dengan pendapatan sekarang" atau "menemukan sangat sulit pada saat ini dengan pendapatan yang ada" serta kategori referensi "sangat sulit memperoleh pendapatan".

\section{Wirausaha}

Wirausaha adalah variabel dummy yang sama dengan 1 untuk wiraswasta dan 0 untuk tidak bekerja sendiri.

\section{Sikap Politik}

1. Kepuasan dengan demokrasi. Kepuasan dengan demokrasi menggunalan skala dari 0 sampai 10 yaitu 0 sesuai dengan orangorang yang sangat tidak puas dengan cara demokrasi bekerja di negara dan 10 bagi mereka yang sangat puas dengan karyakarya demokrasi di negeri ini. Diadopsi dari I. Lago-Peñas, S. Lago-Peñas (2010, 441-453).

2. Kepercayaan pada politisi adalah pada skala dari 0 sampai 10 di mana 0 sesuai dengan mereka yang tidak percaya politisi sama sekali dan 10 bagi mereka yang memiliki kepercayaan penuh. Diadopsi dari I. Lago-Peñas, S. Lago-Peñas (2010).

Definisi operasional variabel dapat dilihat pada tabel berikut :

Tabel 1. : Definisi dan Pengukuran Variabel Penelitian

\begin{tabular}{|l|l|l|}
\hline Variabel & Definisi & Pengukuran \\
\hline Kecurangan pajak & Skala likert 5 poin \\
\hline Tingkat moral perpajakan & $\begin{array}{l}\text { Motivasi intrinsik individu } \\
\text { untuk mematuhi dan } \\
\text { membayar pajak }\end{array}$ & Skala likert 5 poin \\
\hline Umur & Umur responden & Angka numerik (tahun) \\
\hline Tingkat pendidikan & $\begin{array}{l}\text { Tingkat pendidikan tertinggi } \\
\text { yang telah dicapai }\end{array}$ & Kategori \\
\hline Jenis Kelamin & Jenis kelamin responden & $\begin{array}{l}\text { Angka numerik } \\
\text { (dummy: 0,1) }\end{array}$ \\
\hline $\begin{array}{l}\text { Kepuasan terhadap } \\
\text { demokrasi }\end{array}$ & $\begin{array}{l}\text { Tingkat kepuasan pada } \\
\text { demokrasi }\end{array}$ & Skala likert 5 poin \\
\hline $\begin{array}{l}\text { Kepercayaan terhadap } \\
\text { politisi }\end{array}$ & $\begin{array}{l}\text { Tingkat kepercayaan pada } \\
\text { politisi }\end{array}$ & Skala likert 5 poin \\
\hline Pendapatan & $\begin{array}{l}\text { Tingkat kepuasan pada } \\
\text { pendapatan }\end{array}$ & Kategori \\
\hline Self employment & Kepemilikan pada usaha & Angka numerik \\
\hline
\end{tabular}


(dummy: 0,1)

\section{Metode Analisis Data}

Teknik analisis data yang digunakan adalah analisis regresi berganda dengan bantuan software SPSS. Dengan persamaan sebagai berikut :

Persamaan 1

$\mathbf{Y}=\mathbf{a}+\mathbf{b}_{1} \mathbf{X}_{1}+\mathbf{b}_{2} \mathbf{X}_{2}+\mathbf{b}_{3} \mathbf{X}_{3}+\mathbf{b}_{4} \mathbf{X}_{4}+\mathbf{b}_{5} \mathbf{X}_{5}$ Peldgutiantrapotesis menggunakan uji $t$ dengan tingkat keyakinan 95\% dengan Keterangan:

$\begin{array}{ll}\mathrm{Z} & =\text { Tax Morale } \\ \mathrm{a} & =\text { Konstanta } \\ \mathrm{b}_{1,2,3,4,5} & =\text { Koefisien regresi } \\ \mathrm{X}_{1} & =\text { Gender } \\ \mathrm{X}_{2} & =\text { Pendidikan } \\ \mathrm{X}_{3} & =\text { Usia } \\ \mathrm{X} 4 & =\text { Kewirausahaan } \\ \mathrm{X} 5 & =\text { Pendapatan } \\ \mathrm{X} 6 & =\text { Kepercayaan pada politisi } \\ \mathrm{X} 6 & =\text { Kepuasan pada Politisi } \\ \mathrm{X} 7 & \\ \mathrm{e} & \end{array}$

Persamaan 2 :

$Y=a+Z$

$\mathrm{Y}=$ Kecurangan pajak

$\mathrm{Z}=$ Tax Morale degree of freedom (df): $n-k$. Jika $t_{\text {hitung }}<t_{\text {tabel }}$, Maka $\mathrm{H}_{0}$ ditolak dan $\mathrm{H}_{\mathrm{a}}$ diterima. Sebaliknya, jika $t_{\text {hitung }}>t_{\text {tabel }}$, Maka $\mathrm{H}_{0}$ diterima dan $\mathrm{H}_{\mathrm{a}}$ ditolak.

\section{HASIL DAN PEMBAHASAN}

\section{Gambaran Umum Responden}

Dari 100 kuisioner yang disebarkan, jumlah kuisioner yang terkumpul dan diolah sebanyak 64 kuisioner. Gambaran umum responden dapat dilihat pada tabel 2 berikut:

Tabel 2. Identitas Responden

\begin{tabular}{|l|c|c|}
\hline & JUMLAH & PERSENTASE (\%) \\
\hline JENIS KELAMIN & & \\
\hline LAKI-LAKI & 52 & 0.52 \\
\hline PEREMPUAN & 48 & 0.48 \\
\hline JUMLAH & 100 & \\
\hline PENDIDIKAN & & \\
\hline SMA & 17 & 0.17 \\
\hline S1 & 44 & 0.44 \\
\hline S2 & 2 & 0.02 \\
\hline LAINNYA & 37 & 0.37 \\
\hline JUMLAH & 100 & \\
\hline PENGALAMAN KEUANGAN & & \\
\hline USAHA SENDIRI & 54 & 0.54 \\
\hline KARYAWAN & 46 & 0.46 \\
\hline JUMLAH & 100 & \\
\hline UMUR & & \\
\hline $20-25$ & 17 & 0.17 \\
\hline $26-30$ & 28 & 0.28 \\
\hline $31-40$ & 27 & 0.27 \\
\hline $41-45$ & 13 & 0.13 \\
\hline$\geq 45$ & 15 & 0.15 \\
\hline
\end{tabular}

JIAFE (Jurnal IImiah Akuntansi Fakultas Ekonomi)

Volume 3 No. 2 Tahun 2017, Hal. 61-75 


\section{JUMLAH}

Dari 100 responden yang berpartisipasi sebanyak 52 (52\%) orang berjenis kelamin laki-laki dan 48 orang wanita (48\%). Responden dengan tingkat pendidikan SMA 17 orang (17\%), S1 sebanyak 44 orang (44\%), S2 sebanyak 2 orang atau $2 \%$ dan pendidikan lainnya 37 orang (37\%). Responden yang memiliki usaha sendiri yaitu sebanyak 54 orang (54\%) dan sebagai karyawan 46 orang (46\%) yang berusia 20-25 tahun sebanyak 17 orang (17\%), 26-30 tahun sebanyak 28 orang (28\%), usia 31-40 tahun sebanyak 27 orang (27\%) , usia 41-45 tahun sebanyak 13 orang (13\%) dan usia >45 tahun sebanyak 15 orang(15\%).

\section{Hasil Analisis Regresi Berganda}

Dalam penelitian ini, hipotesis diuji dengan menggunakan model regresi linier berganda untuk memperoleh gambaran menyeluruh mengenai pengaruh variabel kebijakan perpajakan, Undang-undang perpajakan, administrasi perpajakan, moral wajib pajak, risiko deteksi, dan sanksi administrasi terhadap variabel perencanaan pajak (tax planning), sehingga didapatkan persamaan 1:

$\mathbf{Y}=\mathbf{a}+\mathbf{b}_{1} \mathbf{X}_{1}+\mathbf{b}_{2} \mathbf{X}_{2}+\mathbf{b}_{3} \mathbf{X}_{3}+\mathbf{b}_{4} \mathbf{X}_{4}+\mathbf{b}_{5} \mathbf{X}_{5}+\mathbf{b}_{6} \mathbf{x}_{6}+\mathbf{e}$

Keterangan:

$\begin{array}{ll}\mathrm{Z} & =\text { Tax Morale } \\ \mathrm{a} & =\text { Konstanta } \\ \mathrm{b}_{1,2,3,4,5} & =\text { Koefisien regresi } \\ \mathrm{X}_{1} & =\text { Gender } \\ \mathrm{X}_{2} & =\text { Pendidikan } \\ \mathrm{X}_{3} & =\text { Usia } \\ \mathrm{X} 4 & =\text { Kewirausahaan } \\ \mathrm{X} 5 & =\text { Pendapatan } \\ \mathrm{X} 6 & =\text { Kepercayaan pada politisi } \\ \mathrm{X} 6 & =\text { Kepuasan pada Politisi } \\ \mathrm{e} & =\text { Error term }\end{array}$

Dari pengolahan data komputer program SPSS, maka persamaan regresi berganda akan terlihat sebagai berikut:

Tabel 3. Hasil Pengujian Regressi 1

Coefficients $^{\mathrm{a}}$

\begin{tabular}{|c|c|c|c|c|c|c|c|c|}
\hline \multirow[b]{2}{*}{ Mode } & & \multicolumn{2}{|c|}{ Unstandardized Coefficients } & \multirow{2}{*}{$\begin{array}{c}\text { Standardized } \\
\text { Coefficients } \\
\text { Beta }\end{array}$} & \multirow[b]{2}{*}{$t$} & \multirow[b]{2}{*}{ Sig. } & \multicolumn{2}{|c|}{ Collinearity Statistics } \\
\hline & & B & Std. Error & & & & Tolerance & VF \\
\hline \multirow[t]{8}{*}{1} & (Constant) & 15.318 & 2.914 & & 5.257 & .000 & & \\
\hline & Gender & .289 & .753 & .035 & .384 & .702 & .988 & 1.012 \\
\hline & Pendidikan & .025 & .379 & .007 & .066 & .948 & .748 & 1.337 \\
\hline & Usia & .077 & .308 & .025 & .249 & .804 & .866 & 1.154 \\
\hline & Kewirausahaan & 1.218 & .818 & 149 & 1.489 & 140 & .836 & 1.196 \\
\hline & Pendapatan & .720 & .461 & .144 & 1.560 & 122 & 992 & 1.008 \\
\hline & Kepercayaan & .301 & .117 & .255 & 2.583 & .011 & .865 & 1.156 \\
\hline & Kepuasan & 1.312 & .473 & 270 & 2.773 & .007 & .887 & 1.128 \\
\hline
\end{tabular}

a. Dependent Variable: TaxMoral 
$Y=15,3+0,28 \times 1+0,025 \times 2+0,077 \times 3+1,2 \times 4+0,7 \times 5+0,3 \times 6+1,3 \times 7$

Hasil Analisis Regressi 2

Hasil analisis regressi 2 dapat dilihat pada tabel berikut:

Tabel 4. Hasil Pengujian Regressi 2

\begin{tabular}{|c|c|c|c|c|c|c|c|c|}
\hline \multicolumn{9}{|c|}{ Coefficients $^{a}$} \\
\hline \multirow{2}{*}{\multicolumn{2}{|c|}{ Model }} & \multicolumn{2}{|c|}{ Unstandardized Coefficients } & \multirow{2}{*}{$\begin{array}{c}\text { Standardized } \\
\text { Coefficients } \\
\text { Beta }\end{array}$} & \multirow[b]{2}{*}{$t$} & \multirow[b]{2}{*}{ Sig. } & \multicolumn{2}{|c|}{ Collinearity Statistics } \\
\hline & & $\mathrm{B}$ & Std. Error & & & & Tolerance & VIF \\
\hline \multirow[t]{2}{*}{1} & (Constant) & 37.517 & 4.421 & & 8.487 & .000 & & \\
\hline & TaxMoral & -.315 & .155 & -.201 & -2.036 & .044 & 1.000 & 1.000 \\
\hline
\end{tabular}

a. Dependent Variable: Kecurangan

$Y=a+Z$

$Y=$ Kecurangan pajak

$\mathrm{Z}=$ Tax Morale

$Y=37-0,315 Z$

\section{Hasil Pengujian Hipotesis}

\section{Hasil Pengujian hipotesis 1}

H1a: Jenis Kelamin berpengaruh terhadap moral pajak.

H1b: Usia berpengaruh positif terhadap moral pajak.
H1c: Pendidikan berpengaruh terhadap moral pajak.

Hasil pengujian hipotesis 1 dapat dilihat pada tabel berikut:

Tabel 5. Hasil Pengujian hipotesis 1

\begin{tabular}{|l|l|r|r|r|r|}
\hline \multicolumn{2}{|c|}{} & \multicolumn{3}{|c|}{ Unstandardized Coefficients } & \multicolumn{2}{|}{} \\
\cline { 3 - 5 } Model & B & Std. Error & \multicolumn{1}{c|}{ t } & \multicolumn{1}{c|}{ Sig. } \\
\hline \multirow{3}{*}{} & Gender & .289 & .753 & .384 & .702 \\
\cline { 2 - 7 } & Pendidikan & .025 & .379 & .066 & .948 \\
\cline { 2 - 6 } & Usia & .077 & .308 & .249 & .804 \\
\hline
\end{tabular}

Hasil pengujian hipotesis 1 yang menyatakan bahwa faktor demografi yang terdiri dari jenis kelamin, pendidikan, usia tidak berpengaruh terhadap moral pajak. Masing masing signifikansi gender 0,702 dengan $t$ statistik 0,384 , pendidikan dengan tingkat signifikansi 0,948 dan t statistik 0,066. Usia memiliki tingkat signifikansi 0,804 dengan $t$ statistik 0,249 . Semua variabel socio demografi memiliki sig $>0,05$ dan nilai $t$ statistik < t tabel 1,96 ( 1 tailed). Dapat disimpulkan bahawa hipotesis 1 ditolak yaitu jenis kelamin, pendidikan dan usia tidak berpengaruh terhadap moral pajak.

Hasil penelitian ini tidak mendukung teori yang diajukan Torgler dan Valev (2010) bahwa wanita memiliki tingkat kepatuhan pajak yang tinggi dan mereka cenderung menghindari risiko untuk melakukan kecurangan. Usia yang matang serta pendidikan yang makin tinggi juga tidak menyebabkan moral pajak yang makin tinggi. Hal ini kemungkinan disebabkan justru pada usia dan pendidikan yang tinggi wajib pajak 
lebih mengetahui cara-cara untuk melakukan penggelapan pajak.

Hasil Pengujian Hipotesis 2

$\mathrm{H} 2$ a: Pendapatan berpengaruh terhadap moral pajak.
H2b: Status wirausaha berpengaruh terhadap moral pajak.

Hasil pengujian hipotesis 2 dapat dilihat pada tabel berikut:

Tabel 6. Hasil Pengujian Hipotesis 2

\begin{tabular}{|c|c|c|c|c|c|}
\hline & \multicolumn{2}{|c|}{ Unstandardized Coefficients } & \multirow{2}{*}{$\begin{array}{c}\begin{array}{c}\text { Standardized } \\
\text { Coefficients }\end{array} \\
\text { Beta }\end{array}$} & \multirow[b]{2}{*}{$\mathrm{t}$} & \multirow[b]{2}{*}{ Sig. } \\
\hline & $\mathrm{B}$ & Std. Error & & & \\
\hline Kewirausahaan & 1.218 & .818 & .149 & 1.489 & .140 \\
\hline Pendapatan & .720 & .461 & .144 & 1.560 & .122 \\
\hline
\end{tabular}

Hasil pengujian hipotesis 2 yaitu status wirausaha dan jumlah pendapatan tidak berpengaruh terhadap moral pajak. Pengaruh kewirausahaan terhadap moral pajak menunjukkan nilai $\mathrm{t}$ statistik sebesar 1,489 dan sig 0,140 . Sedangkan pendapatan memiliki nilai t statistik 1,560 dan sig 0,122. Kedua variabel ini memiliki nilai t statistik < 1,96 dan sig > 0,05 yang berarti hipotesis ditolak. Dapat disimpulkan bahwa walaupun wajib pajak status pekerjaannya sebagai wirausaha atau karyawan tidak berpengaruh terhadap semangat membayar pajak. Jumlah pendapatan juga tidak berpengaruh pada semangat untuk membayar pajak.

\begin{abstract}
Walaupun hasil penelitian ini menolak teori yang dikemukakan sebelumnya, namun analisis menunjukkan bahwa untuk wajib pajak orang pribadi di wilayah Pekanbaru masih memiliki semangat membayar pajak yang rendah.
\end{abstract}

\section{Hasil pengujian hipotesis 3}

H3a: Kepuasan pada demokrasi berpengaruh terhadap moral pajak.

H3b: Kepercayaan pada politisi berpengaruh terhadap moral pajak.

Hasil pengujian hipotesis 3 dapat dilihat pada tabel berikut:

Tabel 7. Hasil Pengujian Hipotesis 3

\begin{tabular}{|c|c|c|c|c|c|}
\hline \multirow[b]{2}{*}{ Model } & \multicolumn{2}{|c|}{ Unstandardized Coefficients } & \multirow{2}{*}{$\begin{array}{c}\text { Standardized } \\
\text { Coefficients } \\
\text { Beta }\end{array}$} & \multirow[b]{2}{*}{$\mathrm{t}$} & \multirow[b]{2}{*}{ Sig. } \\
\hline & B & Std. Error & & & \\
\hline Kepercayaan & .301 & .117 & .255 & 2.583 & .011 \\
\hline Kepuasan & 1.312 & .473 & .270 & 2.773 & .007 \\
\hline
\end{tabular}

Hasil pengujian menunjukkan variabel kepercayaan pada politik dan kepuasan dalam berpolitik memiliki nilai $\mathrm{t}$ statistik 2,583 dan 2,773 serta nilai signifikansi 0,11 dan 0,007 . Hasil pengujian menunjukkan $t$ statistik $>1,96$ dan sig $<0,05$ yang berarti hipotesis diterima. Dapat disimpulkan bahwa kepercayaan pada politisi dan kepuasan dalam berpolitik mendorong wajib pajak dalam membayar pajak. Hasil pengujian ini 
mendukung teori Torgler (2003) yang diajukan bahwa sikap politik merupakan salah satu faktor yang mempengaruhi semangat untuk membayar pajak. Konsisten juga dengan penelitian Lago Penas (2010) bahwa sikap politik mempengaruhi semangat pajak wajib pajak.

\section{Hasil pengujian hipotesis 4}

H4: Moral pajak berpengaruh terhadap kecurangan pajak.

Hasil pengujian dapat dilihat pada tabel berikut:

Tabel 8. Hasil Pengujian Hipotesis 4

Coefficients $^{a}$

\begin{tabular}{|c|c|c|c|c|c|c|c|c|}
\hline \multirow{2}{*}{\multicolumn{2}{|c|}{ Model }} & \multicolumn{2}{|c|}{ Unstandardized Coefficients } & \multirow{2}{*}{$\begin{array}{c}\begin{array}{c}\text { Standardized } \\
\text { Coefficients }\end{array} \\
\text { Beta }\end{array}$} & \multirow[b]{2}{*}{$\mathrm{t}$} & \multirow[b]{2}{*}{ Sig. } & \multicolumn{2}{|c|}{ Collinearity Statistics } \\
\hline & & $\mathrm{B}$ & Std. Error & & & & Tolerance & VIF \\
\hline \multirow[t]{2}{*}{1} & (Constant) & 37.517 & 4.421 & & 8.487 & .000 & & \\
\hline & TaxMoral & -.315 & .155 & -.201 & -2.036 & .044 & 1.000 & 1.000 \\
\hline
\end{tabular}

a. Dependent Variable: Kecurangan

Hasil pengujian menunjukkan nilai t statistik $2,036>1,96$ dan sig 0,044<0,05. Dapat disimpulkan bahwa moral pajak berpengeruh terhadap kecurangan pajak. Hasil pengujian hipotesis 4 mendukung penelitian Torgler dan Schneider(2004) yang menyatakan bahwa moral pajak mempengaruhi perilaku wajib pajak untuk melakukan kecurangan pajak.

\section{PENUTUP}

\section{Kesimpulan}

1. Faktor socio demografi yaitu umur, jenis kelamin dan pendidikan tidak berpengaruh terhadap moral pajak wajib pajak orang pribadi di Kota Pekanbaru.

2. Penghasilan dan status pekerjaan apakah sebagai wirausaha atau karyawan juga tidak berpengaruh terhadap moral wajib pajak orang pribadi di Kota Pekanbaru.

3. Kepercayaan dan kepuasan pada demokrasi dan politik berpengaruh terhadap moral pajak wajib pajak orang pribadi di Kota Pekanbaru. Semakin tinggi kepuasan dan kepercayaan pada demokrasi maka akan meningkatkan moral pajak atau semangat untuk membayar pajak wajib pajak orang pribadi di Kota Pekanbaru.

4. Moral pajak berpengaruh terhadap perilaku kecurangan wajib pajak orang pribadi di Kota Pekanbaru. Semakin tinggi moral pajak maka tingkat kecurangan pajak semakin rendah.

\section{Keterbatasan dan saran}

Penelitian ini memiliki beberapa keterbatasan diantaranya: jumlah sampel yang masih memiliki jumlah yang masih kurang, lingkup penelitian hanya pada satu wilayah dengan populasi yang terbatas, variabel yang digunakan masih terbatas sehingga penelitian ini tidak dapat mengeksplorasi berbagai faktor yang mempengaruhi moral pajak dan dan kecurangan pajak. Sehingga saran untuk penelitian selanjutnya adalah penelitian memperbanyak sampel dan menggunakan wilayah yang lebih luas sehingga hasil penelitian lebih dapat digeneralisasi dan penelitian ini hanya menggunakan variabel religiusitas serta variabel lain yang mempengaruhi kecurangan pajak.

\section{DAFTAR PUSTAKA}

Alm, J., Martinez-Vazquez, J., 2003. Institutions, Paradigms, and Tax Evasion in Developing and Transition Countries. In: Martinez-Vazquez, J., Alm, J. (Eds.), Public Finance in Developing and Transitional Countries 
- Essays in Honor of Richard Bird. Edward Elgar, Cheltenham, pp. 146178.

Allingham, M. G., \& Sandmo, A. 1972. Income Tax Evasion: A Theoretical Analysis. Journal of Public Economics, 1, 323338.

Andreoni, J., Erard, B., \& Feinstein, J. (1998). Tax Compliance. Journal of Economic Literature, 36, 818-860.

Cahyonowati, Nur (2011), Model Moral Dan Kepatuhan Perpajakan: Wajib Pajak Orang Pribadi. JAAI Volume 15 No. 2, Desember.

Frey, B.S., 2002. Direct Democracy for Transition Economies. Paper for the Collegium Budapest. Institute for Advanced Study.

Frey, B. S., 2003. Direct democracy for Transition Countries. Institute for Empirical Research in Economics Working Paper Series, No. 165, July, Zurich.

Friedman, E., Johnson, S., Kaufmann, D., Zoido-Lobaton, P., 2000. Dodging the Grabbing Hand: the Determinants of Unofficial Activity in 69 Countries. Journal of Public Economics 76 (3), 459-493.

I. Lago-Peñas, S. Lago-Peñas (2010) The Determinants of Tax Morale in Comparative Perspective: Evidence from European Countries. European Journal of Political Economy 441-453.

Kirchler, E., Hoelzl, E., and Wahl, I. 2008. Enforced Versus Voluntary Compliance: The "Slippery Slope" Framework. Journal of Economic Psychology, 29, 210-55.

Mustikasari E .2007. Kajian Empiris tentang Kepatuhan Wajib Pajak Badan di Perusahaan di Perusahaan Industri Pengolahan di Surabaya. SNA $X$, Makassar.

Schneider, F. and D. Enste, 2000. Shadow Economies Around the World: Size,
Causes and Consequences. IMF Working Paper WP/00/26, pp. 1-56.

Schimmelfenning, F., Sedelmeier, U., 2004. Governance by Conditionality: EU Rule Transfer to the Candidate Countries of Central and Eastern Europe. Journal of European Public Policy 11 (4), 669-687.

Torgler, B., 2003. Tax Morale in Transition Countries. Post-Communist Economies 15 (4), 357-381.

Torgler, Benno, 2006. The Importance of Faith: Tax Morale and Religiosity. Journal of Economic Behavior and Organization 61, 81-109.Torgler, B., 2007a. Tax Compliance and Tax Morale: A Theoretical and Empirical Analysis. Edward Elgar, UK, Cheltenham.

Torgler, B., 2007b. Tax morale in Central and Eastern European Countries. In: Hayoz, N., Hug, S. (Eds.), Tax Evasion, Trust and State Capacities. How Good Is Tax Morale in Central and Eastern Europe? Peter Lang, Bern, pp. 155-186.

Torgler, B., Garcia-Valiñas, M.A., 2007. The Determinants of Individuals' Attitudes Towards Preventing Environmental Damage. Ecological Economics 63 (23), 536-552.

Torgler, B., Schneider, F., 2007. Shadow Economy, Tax Morale, Governance and Institutional Quality: A Panel Analysis. IZA Discussion Papers 2563. Institute for the Study of Labor (IZA).

Torgler, B., Schneider, F., 2009. The Impact of Tax Morale and Institutional Quality on the Shadow Economy. Journal of Economic Psychology 30 (2), 228-245.

Torgler, B., Schneider, F., Schaltegger, C.A., 2010a. The impact of a Bottom-up Approach on Tax Morale and the Shadow Economy. Public Choice 144 (1-2), 293-321.

Torgler, B., Schaffner, M., Macintyre, A., 2010b. Tax Compliance, Tax Morale, and Governance Quality. In: Alm, J., Martinez-Vazquez, J., Torgler, B. (Eds.), 
Developing Alternative Frameworks for Explaining Tax Compliance. Routledge, London, pp. 56-73.

Wiko. 2015.

http://bisniskeuangan.kompas.com/re $\mathrm{ad} / 2015 / 01 / 14 / 122832126 /$ Realisasi.P ajak

2014.Terendah.dalam.25.Tahun.Terakh ir

www. Kemenkeu.go Id. 